\title{
Investigating the Juristic basis of State and Provincial Commands in the Civil Law of Islamic Republic of Iran
}

\author{
Ardeshir Fathalian (Corresponding author) \\ M.A. in Islamic jurisprudence and law principles at Islamic Azad University, Ilam Branch \\ Ilam, Iran. Phone: 09188345764 Email: fathaliana@gmail.com
}

Dr. Rajab Akbarzadeh

Assistant professor and Faculty Member at Payam Noor University of Babol, Babol, Iran

Phone: 09128516522 Email: rajab.akbarzadeh@yahoo.com

\begin{abstract}
Dr. Ahmad Hosein Falahi
Assistant professor and Faculty Member at Payam Noor Unoversity of Hamedan, Hamedan

Iran. Phone: 09127479719 Email: hmdfalah@yahoo.com
\end{abstract}

Doi:10.5296/ jsr.v6i2.8086 URL: http://dx.doi.org/10.5296/ jsr.v6i2.8086

\begin{abstract}
Governmental commands are commands which the ruler of the society prescribes according to the predicted legal terms and the general well beings of the Muslims to protect the safety of the society and resolve the deadlocks. Guardian jurist's (Vilayat-e Faghih's) and supreme ruler's range of authorizations are complete and full so that Imam Khomeini announced that guardianship should include all issues for which the prophet of Islam and Shia Imams have a responsibility towards it. This study made an attempt to investigate the juristic principles of governmental commands in civil code of the Islamic Republic of Iran. The basis and evidence of the subject were referred to from Quran, narrations, Islamic jurists' and scholar's opinions and the intuition viewpoint. In the civil law of the Islamic Republic of Iran, there are some clauses like 56, 77, 79, 81, 171, 1029, and 1130 which are representative of the influence of governmental command by the supreme leader.
\end{abstract}

Keywords: Jurisprudence, governmental command, guardianship, law, decree 


\section{Introduction}

Islam, by the way of an eternal and complete religion, besides insuring personal needs, answers public needs in region of universal and governmental affairs. This heavenly religion imposed secondary commands besides fabricating some laws named primitive commands to emerge these needs. In the case of inability to act according to primitive commands, secondary commands are provided and finally to unravel political, social, and economical problems, governmental commands are created.

Considering news, narrations, and assembly of scholars, first, Mulla Ahmad Naraghi, testified that among those who have the right of possession and guardianship in most of the cases like “instituting a government, administering peasants' affairs, investigating halal and haram, proving crescent, judging, executing Hodud and Tazirt, occupying of orphans' and the insane possession in the half of the thirteen century" (Naraghi, 1996p.529).

After Naraghi, Imam Khomeini was the first Islamic jurist who discussed scholars and his authorizations circumstantially. He stated that "the same authorizations and guardianship which prophet Muhammad and Imams (peace be upon them) had in preparing and mobilizing corps, specifying the governors, and taxing and spending it for Muslims, Allah set the same authorizations for the present government, but not to a specific person" (Khomeini, 1981, p.64).

Noticing Prophet Muhammad's character sketch ( $\mathrm{Sm})$ and his Imams reveals the key role of governmental commands in trouble-shooting of the problems and difficulties. In the major occultation, Shia could not use their guardianship except in rare cases and in the recent decades, we have just observed some governmental commands of Islamic jurists like Mirza Shirazi for tobacco sanction, Mirza Mohammad Taghi Shirazi's command for crusade against Italy, Russia, and England and some other commands. Considering that our canonical texts are taken from juristic books, there are some topics about governmental commands in some rules of Islamic Republic of Iran. Among these rules, there is civil law of Islamic Republic of Iran, in which some cases are allocated to this topic. So, what we are going to find in this article is to reconsider and criticize these clauses in Quran, narrations, and Islamic jurists' and scholars' opinions.

Islamic government could establish some rules to unravel Muslims' problems in new situations and based on time requirements by the Islamic governor and according to fundamental principles. The Islamic jurist's governmental command is not in contradiction to Islamic principles of Islam, but is also in the framework of Islamic rules. There are subjects about governmental and provincial commands in the rules of the Islamic Republic of Iran among which is civil law which has some clauses related to this topic. The questions are: what are the juristic principles of governmental and provincial commands in civil law of Islamic republic of Iran? What is the place of governmental commands in the common divide of law commands? It should be uttered concisely that the researcher tried to study the juristic principles of these clauses, clarify that Islamic jurist's authorizations are in the framework of Islamic rules and has juristic basis. 


\section{Definitions}

Vilayat (guardianship): literally there is a variety of meaning for the word "vilayat" in dictionary. We refer to some of them.

Raghib said:" they are guardianship (vola) and its consecutiveness; two things are so that nothing comes between them. It metaphorically refers to the closeness of guardianship and its consecutiveness, whether it's in place, or faithfulness, or victory, or belief (RaghibEsfahani,1992).

Vilayah is infinitive of vali. Vilayat means sultan and victory. Vali is the opposite of enemy and means winner and protector (Haumeirig, 2000).

The intention of idiomatic meaning of the word "vilayah" in Islamic jurist is care.

Literal definition and meaning of Hokm (command): considering society member's talent and conducting them to their perfection and ideal form (JavadiAmoli, 1999, p. 121,122,129,136).

Vali is the governor who is responsible for the leadership of the society and care about the general affair and their rank (Ghasemi, 2006).

The Quran words define Hokm: "hokmaslaho: mae manna la selah"; hokm means forbidding a ban for correction (RaghibEsfahani, 1992).

Hokm is a reference for correction and judgment. In the lexicon, it means making firm and settle which prevent corruption. So the first meaning of this word is preventing corruption for correction and it refers to all matters (Ghoreishi, 1992).

Governmental commands: it has some other names like: "juristic command", "governor command", "provincial command", and "variable command".

Governmental commands are decisions which the Islamic governor make, considering religion rules and respecting their agreement, based on time requirement. "This juristic command lasts till there is a requirement and if the requirement fades, the basis of the command will be cancelled"'(Tabatabaee, 1983, p.65).

So, governmental commands are commands which the governor of the society arrange based on predicted rules and according to Muslims' general affairs to protect the safety of the society, set affairs, and establish true relations between organizations in cultural, educational, taxing matters.

The meaning of governmental and juristic commands:

A. The difference between Hokm (command) and Fatwa (religious decree):

Fatwa is from the news category and means the Allah's general commandments about general topics derived from the four sources of Islamic law (the Quran, sunnah, jima (consensus), and agl (the intellect), which may be according to the reality or not, But Hokm is from composition category and is a law issued by the Islamic governor. Its basis is the well-being which the Islamic governor finds to manage the society. 
B. The characteristics of governmental and juristic commands:

There are some disagreements among Islamic jurists whether governmental command is a primary or secondary command. Imam Khomeini (ra) said:" Islamic jurisprudence and governmental commands are primary commands." (Imam Khomeini, Sahifeh Noor, volume 17, 20, p.174, 202).Allame Tabatabaee finds the governmental command different from primary command and says governmental commands are established based on temporal well-being.

Martyr Mohammad Baghir Sadr considers governmental commands as secondary command and says: Islamic jurist has permission to announce every activity or action, which its necessity is not mentioned explicitly, as banned or irrevocable secondary command (Sadr, 1988).

Ayatollah Javadi Amoli said: those commands, from the governor and the government, are sometimes primary and sometimes secondary; the governor command which announces tonight as the first day of Zihaje or today as the Tarvie and so the pilgrims of Kaaba should move from Mecca to Arafat, these commands and those like them are primary commands. They are not related to secondary commands and their causes have no emergency or sin... If a matter has its own command by keeping its natural and primary title, but the governor realizes another title for that matter so that there is a new command about it and the Islamic governor by supporting that new title, have a special command for it; this type of command is secondary (Javadi Amoli, 1999).

Ayatollah Alavi Gorgani knows governmental command beyond primary and secondary commands and Ayatollah Makarem Shirazi believes that governmental command is not a judicial command to determine whether it is primary or secondary, but governmental command is along with the primary and secondary commands and it has an executive characteristic (the collection of Imam Khomeini's (ra) works Congress of Studying Juristic Principles, volume 14, p. 14).

So, it seems answering to this question: "whether governmental command is a primary or secondary?" considering the differences between Islamic jurists' opinions about this matter, is various and maintains four ideas.

C. Criteria for governmental commands:

The criteria and basis of governmental commands are general well-being of Islamic system and the Islamic jurist should consider the Muslims' general well-being.

Another matter, which gives flexibility, mobility, and adjustment to Islamic laws and keeps them eternal, is the existence of a range of controlling rules among Islamic laws. Islamic jurists chose a beautiful name for it, "governor laws", means the laws which consider all the commands and rules and control them. "Haraj" (no sin) law and "La-zarar" (no loss) law are among these rules. In fact, Islam takes into consideration ballot right for them.

D. Irrevocability of governmental commands: 
One thing more is the irrevocability of governmental commands. We can refer to the verses of Quran, a variety of narrations, and the intuition reasoning, emphasizing to follow the governmental commands. Some of them are mentioned concisely in the following:

1. Verses of Quran:

"O you who believe! Obey Allah and obey the Messenger (Muhammad) and those of you (Muslims) who are in authority..." (Nisa, 59)

2. Narrations: it was mentioned in some of the accepted narrations from Omar Bin Hanzale:

Said: look at that who narrate our narrations, observe our Halal and Haram and know our commands, so if you get satisfied with the commands of that person, we choose him as your governor, if he commands according to our commandments and you don't accept him, it's like you reject our commandments. Those who reject our commands reject Allah's commandments and this equals polytheism of Allah.

3. Intuition (aql):

Intuition, as the Devine talent in the inside of human being, accepts that, in the deadlocks, the Islamic governor gives a command or stem the loss or depravity by his command to leave the current circumstances. In fact, governmental command from the Islamic governor is not in conflict with the intuition, but the intuition approves it.

The juristic principles of governmental and providential commands:

The juristic principles of governmental commands are the Quran, sunnah, jima (consensus), and aql (the intellect). In this part, all of them will be discussed one by one:

1. The verses of Quran:

A. "O you who believe! Obey Allah and obey the Messenger (Muhammad) and those of you (Muslims) who are in authority..." (Nisa, 59)

In Imam Khomeini's (ra) point of view, the meaning of "ulil al-amr" is obeying governmental and provincial as he said in the book named al-Bie (selling): the purpose of "obey the messenger and those of you who are in authority" is obeying the governmental and provincial commands, not the Devine commandments. (Imam Khomeini, Al-Bie. Volume 2, p.477)

B."The Prophet is closer to the believers than their ownselves." (Al-Ahzab, 6)

AlameTabatabaee also said: "the meaning of superiority in this verse is the superiority in all the religious and mundane matters because it enfolds all the matters." (Tabatabaee, 1991, p.432)

C. "(And) if you differ in anything amongst yourselves, refer it to Allah and His Messenger, if you believe in Allah and in the Last Day. That is better and more suitable for final determination." (Nisa, 59)

This verse contains both government and judgment and juristic command is a branch of provincial command of those in authority. So, obey the "Vali Amr" is mandatory to all people. 
People should consult him or those who he chose, in their disputes and quarrels and accept his commands which are governmental and provincial.

D.'It is not for a believer, man or woman, when Allah and His Messenger have decreed a matter that they should have any option in their decision. And whoever disobeys Allah and His Messenger, he has indeed strayed in a plain error." (Al-Ahzab, 36)

AllameTabatabaee wrote in the interpretation of this verse: none of the faithful women and men has the right to defy Allah or His Messenger decision about one of their affaires and accept something except what Allah ordered, but they should follow Allah and His Messenger decision. (Tabatabaee, 1983)

In this verse, the Messenger's guardianship is the guardianship of commandments and management which causes Islam protection and punishment of criminals, management of affairs and protection of general affairs, and rejection of corruption which threats a nation, and causes their weakness and their enemy's strength. According to this verse, the guardianship of governor and Islamic jurists to achieve the above aims is absolute and it can be generalized that following "Vali Amr" and Islamic jurists is mandatory in major occultation, and their guardianship is like the Messenger's guardianship which is mentioned in this verse. (Golpaygani, 1989)

E."Verily! Allah commands that you should render back the trusts to those, to whom they are due; and that when you judge between men, you judge with justice. Verily, how excellent is the teaching which He (Allah) gives you! Truly, Allah is Ever All-Hearer, All-Seer." (Nisa Surah, 58)

Imam Khomeini believes that this noble verse appears in the government affairs and it can be a justification to issue governmental commands from Vali Amr. (Imam Khomeini, p.107, 108, 109)

F. "And whatsoever the Messenger (Muhammad) gives you, take it, and whatsoever he forbids you, abstain (from it)." (Al-Hashr, Holly Quran, 7)

This noble verse comes from Allah to the prophet about how to share the possessions which the Muslims took from the Jewish of Bani Nazir without quarrel or struggle, and gave authorizations from Allah to prophet to share the possessions according to his expediency.

It is cited in Majma Al-Bayan, about the interpretation of this verse: Allah specified the possessions of Bani Nazir to his prophet to decide about them. The prophet shared them between Mohajerin (the immigrants) and did not give anything to Ansar(the Helpers) except to three of them who were poor and their names are Abu Dejane, Sahl Bin Hanif, and Hareth Bin Samme. (Tabari, 1988)

2. Narrations: the second principle of governmental commands is the narrations of Ma'sumin (the Sinless prophet and Imams). There are lots of narrations which refer to the authorizations of the Islamic governor. On the other words, the authorization of issuing governmental commands can be derived from them.

A. Omar Bin Hanzale said: I asked Imam Sadegh (peace be upon him) about two of our 
friends (Shia) who had a quarrel about inheritance or debt and they came for judgment. I asked: "is it lawful?" He answered: "Everyone who went to them for judgment about right or unjustifiable quarrels, in fact, he went to Taghut, means illegitimate governmental authority and whatever he gets according to their command is, in fact, unjustifiable, although, whatever he gets is his fixed right. Because he gets it according to Taghut opinion, and Allah commands to be unbeliever to them. I asked: "what should they do?" He answered: "they should search and find one of you who narrates our narrations, studies about Halal and Haram, is learned, and knows our commands and laws... they should accept him as the judge and arbitrator because I put him as your governor. (Bejnourdi Mousavi, 1999)

B. It is cited in Mashhoore Abi Khadeeja: some of you refuse to go to injustice courts and visit a man among you who is aware of the commands of Ahle Beit (people of the house) because I appoint that person as your judge, take the trial to him.(Sadough, 1993)

C. Imam Ali said:I do not lay Had (punishment) in the enemy's realm because there is a dread that by executing Had, he may join the enemies and also said: I don't fulfill Had to anyone in enemy's realm. (Ameli, 1988)

D. Imam Ali put two dinars for a blood stock and a dinar for a non-blood stock as Zakat (alms-giving). (Ameli, 1988, p.51)

E. A person asked Imam Sadegh about permit to buy green fruit. Imam answered: in the Messenger time, there was a quarrel about this matter, and because the prophet realized that the quarrel would not be solved, he prohibited selling the unripe fruit but he did not boycott and the prohibition was because of hostility. (Ameli, 1988, p.53)

F. The Prophet ordered Muslims to change their beard (color it), and don't make themselves like Jewish.

Motahari said about it, this command was a governmental command because when the number of Muslims was a few, enemies think that they were some old men in battles and became more courageous, but in Imam Ali time, they did not need this and he did not color his beard. (Motahari, 1994)

G. Hanife Bin Mansur narrates from Imam Sadegh who said: "In the Messenger time, there was a shortage of food, and the Muslims came to the prophet and said prophet! No one has any food except one person; order him to sell the food. Imam Sadegh said: the Messenger of Allah (peace be upon him) after glorifying and praising Allah said: Oh you! Muslims mentioned that food is rare except with you. Take it and sell it however you want, and don't hoard it up. (Ameli(Hor), 1988)

H. They asked Imam Sadegh: Do women inherit from land? Imam answered: No, (they don't inherit from land), but they inherit from the land price. I said: people don't like this. He answered: when we had guardianship and they did not like this, we lash them and if they did not become dutiful, we cut them with sword.

3. Ijma (consensus): the consensus of Islamic jurists to form Islamic government is a clear and essential matter to execute Hodud (punishment) and laws and stabilize affaires. On the 
other hand, the necessity of executing the governor's commands for people and other Islamic jurists is subject to consensus. Now as evidence to this claim, we provide some of the Ulama and Islamic jurists' opinions and explain about the topic:

A. Saheb Javaher: All the companions of the prophet have unity of opinion on this: the just and trustworthy Islamic jurist, who has all the circumstances of Fatwa (decree) and is called Mujtahed Idiomatically, in the major occultation, is the successor of the sinless Imams (peace be upon them). His succession "is about all the matters which the sinless imams participate in. of course, some of the companions exclude murdering and executing Hodud" (Najafi, 1984, p.396).

B. Maverdi: Imamat (spiritual leadership) is established for the succession of the great prophet (peace be upon him) to protect the nation and use tact about the mundane affairs of the nation and it is essential to conform it about one of the people who gets the responsibility of these affairs according to Ulama's consensus. Although a few like "Abu Bakr Asm" rejects the necessity of this. (Maverdi, 1986, p. 5)

C. Naeeni: the departed Naeeni said: it is one of the certainties of the religion to approve guardianship of Islamic jurists, during the major occultation, to execute the mentioned duties (protecting Islamic nation and using tact in Muslims' affairs). (Naeeni, 2006)

4. The intuition: the fourth principle of governmental commands is the intuition. It is essential to have an Islamic jurist at the top of the government and issue commands and orders based on the well-beings. As, most of the scholars and Islamic jurists said: if we don't have any other evidence to confirm Islamic governor at the top of the Islamic government, the intuition reasons are enough to confirm this important matter. On the other way, the intuition testifies the necessity of having a governor, or ruler and all the Islamic jurists accept this matter.

The juristic principles of some of the matters in civil law which guarantee governmental and provincial commands:

In the civil law of Islamic Republic of Iran, there are some clauses which guarantee the governmental commands. These clauses are evidence of provincial commands which are issued by the governor (Islamic jurist). The governmental commands of the governor are effective and irrevocable according to this. We review some of these clauses in the following:

Clause 28 and clause 171:

A. Clause 28:those properties of unknown owner are expropriated by the permission of the Islamic governor and spend for the poor.

B. Clause 171: anyone who finds a lost animal, he should deliver it to its owner and if he does not know its owner, he should deliver it to the Islamic government. Otherwise, he will be responsible for it, even if he releases it after possessing.

These two clauses, in which properties of unknown owner and lost animals are defined by the permission of the Islamic governor or the authorized individuals selected by him, are representative of the governor's guardianship on others. The documents approve this point, 
too. The martyr Sani said: if the property which has been found is of unknown owner, it should be kept for its owner or it should be delivered to the government. (Ameli, p. 544)

Mohaghegh Helli said: "If anyone found a camel, he should deliver it to its owner, and if he did not find its owner, he should deliver it to the government. So, as the prophet and Imams had general guardianship, in the major occultation, the Islamic jurist has a general guardianship and as the sinless Imam had the authority to expropriate the properties of unknown owner, in the occultation, the Islamic jurist has this permission.

Clause 79:

"Vaghif (settler of a pious foundation) or governor could not dismiss the one who was Motevali (custodian) at the time of the contract of Vaghf (pious foundation), unless, dismiss right is mentioned and if betrayal of the custodian reveal, the governor is trustworthy annexation."

This clause defines another matter of guardianship of the Islamic governor and his authorizations, and it is mentioned if custodian of the pious foundation, chosen by the settler of the pious foundation, doesn't do his duty well and betray, the Islamic governor have the right to keep a trustworthy person to do the tasks related to the pious foundation with the traitor.

But some of the Islamic jurists believe, considering the broadness of his authorizations, remove the treacherous custodian and settle a trustworthy person. As departed Naraghi said: In case, the custodian betrays the pious foundations, it's essential to dismiss him and after proving the betrayal, the fully qualified Mujtahid settles another person. (Naraghi, 1997)

Removing the treacherous custodian by the Islamic governor (fully qualified Mujtahid) is acceptable if we assign the governor (Islamic jurist) as guardian and accept that the Islamic jurist is superior to Muslims and rule the life, possession, and other things of Muslims because one of the definitions of Vilayat by the Islamic jurists is this. (Tabatabaee Yazdi, 1994)

Some of the Islamic jurists believe that, in case, the custodian was settled by the settler of the pious foundation and the custodian betrayed the pious foundation, it is not permissible that the Islamic governor remove him, but the governor is just trustworthy annexation in this case.

As an example, Sayed Hassan Bojnoordi in "Al-Ghavaed Al-Faghihe" said: if it is determined that the custodian is treacherous so that the custodian neglect, and destruction and ruin of the pious foundation may happen, it is not unlikely that joining a trustworthy person, selected by the Islamic governor, to the custodian of the pious foundation is essential (Golpaygani Mousavi, 1989)

It is also cited in "Majma Al-Masael" that the Islamic governor is allowed to decide about the treacherous custodian and if the custodian neglects, the governor have the authorization to remove him (Golpaygani Mousavi, 1989) 
According to whatever mentioned, the decisions which the Islamic governor makes are based on the authorizations that the religion gave him and essentially people need a governor to lead them and prevent chaos and the factors which harm them.

Clause 81:

"The public pious foundations which have no specified custodian, conducting it is according to the Islamic jurist's opinion."

Among the words of Ulama about this clause, we can refer to departed Naraghi who settle this right for the lawful governor to decide about public pious foundation so that he said: "whenever the settler of the pious foundation specify a custodian, he has the authority to occupy there, but if the pious foundation is public or its settler is not obvious, the Islamic governor, who is fully qualified, decide about it (Naraghi, 1996).

The departed She'rani also referred that the fully qualified Mujtahid is superior to other in deciding about the public pious foundation. He said: "if the settler do Vaghf and does not specify custodian, deciding about it is by the owners, but if it is public, and it's owner is not specified, the Islamic governor decide for them, because in specified pious foundation, there is no one superior than the settler of it and in public pious foundation, it is essentially advisable for someone to interfere, and the Islamic governor is superior than other. If he chooses somebody, it is not essential for that one to accept, but if he accepts, it is not permissible to quit or be replaced by another one." (Sherani, 1999, p. 465)

The clause 81 of civil law of the Islamic Republic of Iran which gave the Islamic jurist to decide about the public pious foundation, in case there is no specified custodian, is taken from the public guardianship that we attach the fully qualified Mujtahid according to verses of Quran and narrations. In fact, this clause (clause 81) is an evidence for governmental commands by the fully qualified Islamic jurist which he interfere based on his authorizations. Of course, his interference is not based on his fancies, but on Islam religion and law framework.

Clause 59:

Whenever all the partners are willing to share their common possessions, it is done so that the partners are satisfied, in case, the partners don't come to an agreement, the governor force them to share, provided that it does not contain loss. In this case, the force is not permissible and they should be satisfied.

Sharing the common possessions among partners, in case of their satisfaction and no loss is a proper matter which as its consequence, everyone get their share. Aghabe bin Khaled narrated Imam Sadegh a narration; that Imam said: "the Devine Messenger (peace be upon him) judged about the Shafe' (the priority of the partner) of land and house and said there is no loss and no loser and if a sign is laid and the boundaries of possession are specified, there is no Shafe'." (Sadugh, 1993, p. 76)

The opinion of some of Islamic jurists is as following: 
Sheikh Tusi said: sharing possessions have three kinds; first, sharing the possessions and forcing the abstainer are permissible for the Islamic governor. Second, sharing possessions is permissible but forcing an abstainer is not permissible. Third, sharing possession and forcing the abstainer are not permissible. So, whatever is permissible to share or force to share, is a common possession which has equal segments and there is no loss in sharing and in this case, sharing the possession, by the Islamic, is permissible considering the partners' satisfaction. But if some of the partners are willing to share the possession and some others are not willing, the Islamic governor forces the abstainer to share. (Toosi, 2009)

Mohaghegh Helli said in "Sharaye": in the common possession, if there is no loss in share and one of the partners is willing and the other is not willing to share, the Islamic governor forces the one who is not willing to accept the share.

Saheb Jawaher recognized the Islamic governor or the trustworthy person who he chooses, are responsible to share the common possessions in which there is an abstainer and he said: "about sharing possessions, in which there is no loss to one of the partners, while a partner ask for sharing, the abstainer is forced to share... the Islamic governor or his trustworthy person is responsible for executing this" (Najafi, 1984, p. 384).

So, what is popular among the Islamic jurists is that the governor has to force the abstainer to share the possessions, while there is disagreement between the partners, considering that forcing the abstainer harms none of the partners. Clause 591 of the civil law is precisely taken based on this popular word of Islamic jurists.

\section{Conclusion}

In the civil law of the Islamic Republic of Iran, there are some clauses which guarantee governmental commands, in fact, the content of these clauses are taken from provincial authorizations that we proved for the Islamic governor (fully qualified Islamic jurist) using documents.

The Islamic governor has the authorization and can interfere based on some clauses of civil law like: he can take the possession of unknown owner or lost animal and give it to the poor (clauses 28,171), or according to the clause 56, agreement of the Islamic governor is a condition in public pious foundation, which their settler is unknown, gathering trustworthy people by the governor which is referred to in clause 79 , deciding about public pious foundation by the governor (clause 81), forcing Multazm to do the condition, by the governor (clauses 237,238), forcing to share the common possession among the partners by the governor(clause 591), forcing the abstainer to participate in repairing subterranean canal and so on by the governor(clause 594), forcing the mortgagor to pay the mortgaged (clause 779), interference of the governor in selecting one who holds the possession after the death of the mortgaged (clause 788), the governor's permission to rent in order to establish some changes inrenting, in case the mortgaged does not reject the changes (clause 794), forcing the inheritors to announce their decision whether they accept or reject the inheritance (clause 866), divorcing a wife whose husband is gone for four years (clause 1029), forcing the husband to divorce his wife, in case, he avoids to pay her Nafagha ( the money which 


\section{Macrothink}

Journal of Sociological Research

ISSN 1948-5468

2015, Vol. 6, No. 2

husband should pay his wife regularly) (clause 1129), forcing the husband to divorce his wife, by the governor, in case, continuing the marriage causes the wife to be in difficulty or sin (clause 1130) and ... all of these are reasons for the guardianship which is proved about the Islamic governor(Islamic jurist).

All these clauses, which are mentioned about civil law, guarantee the governmental commands. The Islamic jurist, based on the public guardianship which he has, is superior to Muslims. He commands according to the law La-Zarar (no loss), and La-Haraj (no sin), considering time and Muslims' well-being. Concisely, the governor's command in all of the mentioned clauses is a reason for the broadness of governor's authorizations which has juristic principle and all those clauses prove governmental commands.

\section{References}

Ameli, ShahidSani, Z. A. I. A. (1993).Mala pathways To The revision of The Laws of Islam. Qom: The Islamic Knowledge Institute.

Ameli(Hor), Mohamad. I. H. (1988). Means of the Shiites The Islamic Offices. Tehran: Holly Press.

BejnourdiMousavi, S. A. (1999). The rules of Jurist. Qom: Al Hadi Emission.

Ghasemi, M. A. (2006).Jurist and rings of the Supreme leader. Mashhad: Islamic University Razavi Publications.

Ghoreishi, S. A. A. (1992).Quran Lexicon. Tehran: The Islamic Daralketab.

GolpayganiMousavi, S. M. R. (1989). The Collection of Issues, Envision of Qom: New Press.

Haumeirig N. B. S. (2000). Sun of Science and medicine of language of the Arabs of Alklom. Beirut: Daralfekralmaser.

JavadiAmolli, A. (1999). Supreme leader, The provincial of Fqahat and Justice. Qom: Asra Press.

Khomeini, R. (1981). Supreme Leader. Tehran: Amir Kabir Publications.

Naeeni, M. H. (2006).Alert the nation and disliked the people. Tehran: Joint Stock Company.

Najafi, M. B. H. (1984).Jawahraklam to explain the Canons of Islam.Bairut: The Arab heritage Darahia.

Naraghi M. B. A. (1996). Epistles and issues Congress of Nraqyyn of Mla Mahdi and Mola Ahmad. Qom: Express Press.

Naraghi M. B. A. (1997). Returns of days In Statement of Rules of dooms. Qom: The Islamic Publicity.

RaghibIsfehani, H. B. M. (1992). The Mofradat Al-Alfaz,Daralalm. Lebanon-Syria: Darashamih. 


\section{Macrothink}

Journal of Sociological Research

ISSN 1948-5468 2015, Vol. 6, No. 2

Sadough, M. B. A. (1993).Do Not Attend From Jurist, Office of Islamic Publication dependent to Society of teachers in Seminary of Qom. Qom: New Press.

Sadr, S. M. B. (1988).Our economy. Birut: Daraltaref.

SaffiGolpiganiy, L. (1984). Discretionary, Ordinances and Boundaries. Qom: The Islamic Emission Institute.

Sherani, A. (1999). Thoughtfulness of Learners in the Provisions of The religious. Tehran: The Islamic Publications.

Tabarsi, S. A. F. (1988).Collection of Statements. Beirut: Daralamarafh.

Tabatabaee, S. M. H. (1983).Al-Mizan fi Tafsir Al-Quran. Qom: Divine Press.

Tabatabaei, S. M. H. (1991).Spirituality of Shia. Tehran: BitaBino.

TabatabaeiYazdi, S. M. K. (1994). Teklamatolvosgha. Qom: Divine Press.

Toosi, A. J. M. (2009). Almertazavih for revive of Al Jaafarin works. Tehran: Game No. 